\title{
Changes in land use in Mato Grosso do Sul
}

\author{
Fernando Mendes Lamas ${ }^{1}$, Alceu Richetti ${ }^{1}$ \\ ${ }^{1}$ Embrapa Agropecuária Oeste, Dourados, Mato Grosso do Sul, Brasil. E-mail: fernando.lamas@embrapa.br, \\ alceu.richetti@embrapa.br
}

Received: 07/08/2019; Accepted: 06/11/2019.

\begin{abstract}
Among the species cultivated in Mato Grosso do Sul, the area with soybeans is larger than that only for pasture cultivation. This work was developed in fourteen municipalities of the state. Based on information from the Brazilian Institute of Geography and Statistics (IBGE), the evolution of the area occupied by soybean, pasture and sugarcane in these municipalities was analysed. In particular, the area cultivated with soybeans has shown constant and significant growth. On the other hand, the pasture area has been continuously decreasing, especially in Ponta Porã, Maracaju and Rio Brilhante. The areas previously occupied with pastures are giving way to soy and sugarcane cultivation.
\end{abstract}

Keywords: Acreage, soybean, sugar cane, pasture.

\section{Alterações no uso da terra em Mato Grosso do Sul}

\section{RESUMO}

Dentre as espécies cultivadas em Mato Grosso do Sul, a área com soja é maior apenas do aquela destinada ao cultivo de pastagem. O trabalho foi desenvolvido em quatorze municípios do Estado. A partir de informações do Instituto Brasileiro de Geografia e Estatística (IBGE) foi analisada a evolução da área ocupada com soja, pastagem e cana-de-açúcar nestes municípios. A área cultivada, especialmente, com soja vem demonstrando constante e significativo crescimento. Por outro, a área com pastagem vem apresentando contínuo decréscimo, especialmente em Ponta Porã, Maracaju e Rio Brilhante. Áreas anteriormente ocupadas com pastagens estão cedendo espaço para o cultivo de soja e cana-de-açúcar.

Palavras-chave: Área cultivada, soja, cana-de-açúcar, pastagem. 


\section{Introduction}

Soybean is a product with strong liquidity and generally has trade values considered remunerative, which has provided a price support framework domestically, reinforcing producers' commitment to increase the area planted with this crop (Conab, 2019a). Brazil has soybean cultivation technologies that allow it to obtain yields well above the current average of 3,182 $\mathrm{kg} \mathrm{ha}^{-1}$, with significant gains in profitability. Thus, a permanent large-scale technology transfer effort needs to be implemented so that the increase in future soybean production in Brazil is mainly due to increased productivity, without pressure to expand the agricultural frontier (Contini et al., 2018).

Among the buyers of soy agribusiness products, China dominates grain imports, while the European Union should remain the main importer of soybean meal, although developing countries tend to have more market share (Hirakuri and Lazzarotto, 2014). According to forecasts, soybeans will have high growth rates in Mato Grosso, Minas Gerais, Bahia, Goiás and Mato Grosso do Sul; the increase will be greater than $40.0 \%$ over current production (O Futuro..., 2018). Increasing productivity will account for most of the increased production.

In Brazil, the pasture area has been decreasing, especially since 2007. According to Nogueira (2019), in 1990, the pasture area was over $190 \mathrm{M}$ ha, while in 2018 it was $160 \mathrm{M}$ ha. On the other hand, meat production in arrobas/hectare/year jumped from 1,5 to 4,5. A similar trend has been observed in Mato Grosso do Sul, where the pasture-occupied area has gone from 25 to 18.6 million hectares in the last nine years (Semagro, 2018). According to the same source, pasture has been replaced by eucalyptus, sugar cane, soybean and rubber.

The production of sugar cane cultivation has been undergoing spatial changes in Brazil, characterized by three main movements: a) a strong reduction in the relative participation of the Northeast Region in the total planted area in the country; b) growth in the participation of the Southeast Region, especially in the states of Minas Gerais and São Paulo; and c) a greater role in the Midwest Region, especially in the period of sugarcane expansion after 2002/2003 (Embrapa, 2018). In the Midwest Region, Mato Grosso do Sul became one of the states with the strongest growth in sugarcane cultivated area, occupying 795.5 thousand hectares (Conab, 2019b). The expansion of cultivated areas with soybean and sugarcane has been mainly in areas previously occupied by pastures with some degree of degradation (in most cases). One of the consequences of this expansion is the greater dynamism of the macroeconomics of the regions where there is an increase in the area cultivated with soy and sugar cane.
The objective of this study was to analyse land use changes in the state of Mato Grosso do Sul based on data provided by the main institutions that work with statistical agricultural data. In particular, we analysed, land use changes in relation to areas occupied by soybean, sugarcane and pasture in the municipalities that produce grain and sugarcane.

\section{Material and Methods}

This study was developed in four sections. In the first section, an analysis of the evolution of the planted areas, production and average yield of soybean and sugarcane crops in Brazil from 1980 to 2019 was conducted. In the following part, the evolution of areas planted with soybean, sugarcane and pastures in Mato Grosso do Sul from 1995 to 2017 was analysed. In the third part, the evolution of areas planted with soybean, sugarcane and pastures in the period from 1995 to 2017 in 14 of the 79 municipalities in the state of Mato Grosso do Sul, namely, Angelica, Aral Moreira, Chapadão do Sul, Costa Rica, Dourados, Ivinhema, Laguna Carapã, Maracaju, Navirai, New Dawn of the South, Ponta Pora, Rio Brilhante, Sidrolândia and Sonora, was analysed. Additionally, in the third part, we analysed the total area of the municipalities and the percentage of area occupied with sugarcane and soybean in 2017. It is noteworthy that the information on the area cultivated with each of the analysed species, both from Brazil and from the state of Mato Grosso do Sul, was provided by the Brazilian Institute of Geography and Statistics (IBGE).

\section{Results and Discussion}

\subsection{Evolution of soybean acreage in Brazil}

As shown in Figure 1, it was possible to evaluate the evolution of the cultivated area, the production and the yield of soybean in Brazil from 1980 to 2019. As far as the cultivated area is concerned, it went from less than 20,000,000 ha in 1980 to almost 40 million ha in 2019, that is, in almost four decades, the area of soybean cultivation has doubled. Productivity during the period jumped from 1,700 to $3,200 \mathrm{~kg}$ ha-1 (88.23\%). According to Hirakuri (2017), soybeans have a solid international market and a well-defined and structured national production chain. This well-defined chain, with state-of-the-art soybean technology, has allowed Brazilian productivity to double in four decades (Figure 1). The favourable soybean market in recent years has promoted the advancement of culture throughout the Brazilian territory, from the gaucho pampa to the savannahs of Mato Grosso and the MATOPIBA (Maranhão, Tocantins, Piauí and Bahia) region. Projections made by the Fiesp (2018) show that by 
$2027 / 2028$, the soybean cultivation area in Brazil is expected to increase by $21 \%$. In the same paper, the authors estimated growth of $34 \%$ in the Midwest by $2027 / 2028$.

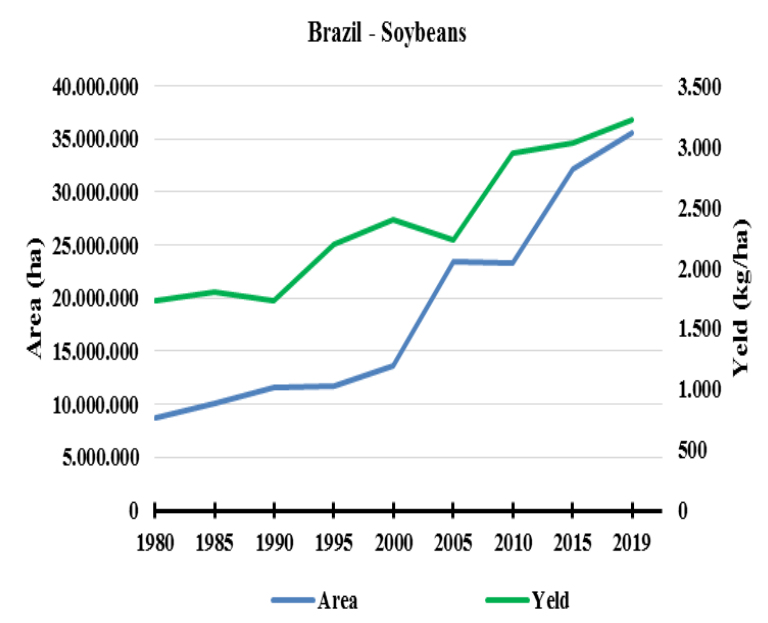

Figure 1. Planted area, production and average yield of soybeans in Brazil from 1980 to 2019. Source: IBGE, 2019a

\subsection{Evolution of sugarcane cultivated area in Brazil}

Regarding sugarcane, there was some seasonality in the cultivated area. However, from 1980 to 2010, both sugarcane production and productivity increased, especially in the Midwest Region (Figure 2). The improvement in sugarcane productivity was due to the incorporation of new varieties and improvements in the soil and crop management systems.

According to Conab (2019b), the yield in Mato Grosso do Sul was estimated at 74 t/ha. This productivity was higher than that in the state of São Paulo and lower than that in the state of Paraná. The climatic conditions of the state of Mato Grosso do Sul, especially the low temperatures from May to July and the occurrence of frost, explain the low productivity of sugarcane in the state.

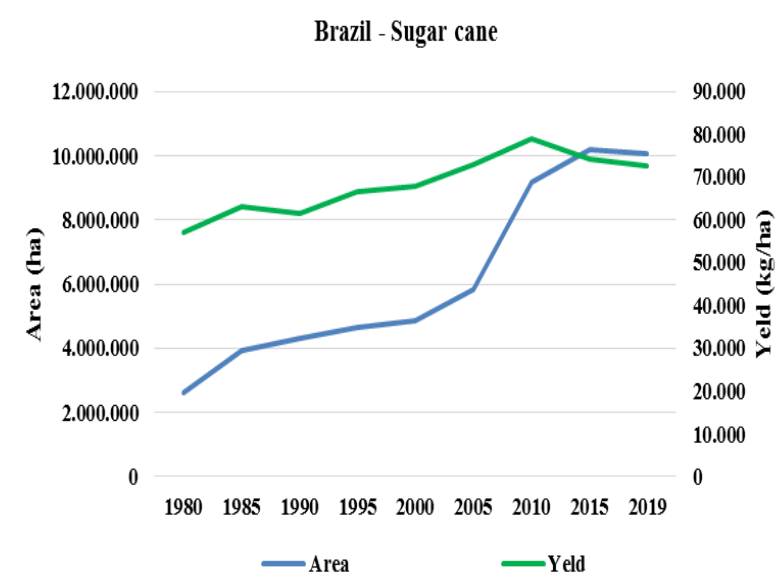

Figure 2. Planted area, production and average yield of sugar cane in Brazil from 1980 to 2019. Source: IBGE, 2019a.

\subsection{Evolution of the area cultivated with soybean, sugar cane and pasture in the state of Mato Grosso do Sul}

In Mato Grosso do Sul, soybeans are grown in almost all the municipalities, except those in the Pantanal region. Among the agricultural products, soy occupies the largest cultivated area, providing conditions for the consolidation of chicken, pork and fish production (Brasil, 2018), thus driving the state's economy through income generation, jobs and diversification of the economic matrix. In addition, soy contributes to the trade surplus, being surpassed by only pulp export.

During the period analysed, from 1995 to 2017, the areas cultivated with soybean and sugarcane showed linear growth (Figure 3). This growth was mainly found in areas previously occupied by pastures. The establishment of 19 sugar and ethanol production units in the state was decisive for the growth of the area cultivated with sugarcane (Biosul, 2019). In the period analysed, there was a significant reduction in area cultivated with pasture (15\%), especially since 2006 (Figure 3).

Streck et al. (2018), in a diagnosis of land use change for soybean production in Rio Grande do Sul, reported that the expansion of soybean cultivation in the Central-South Region occurred mainly in areas previously used for pasture and rice cultivation, similar to what occurred in Mato Grosso do Sul.

The soybean acreage in the state of Mato Grosso do Sul is surpassed only by the pasture acreage (Figure 3 ). In addition to its economic importance, soybean cultivation has great social appeal, and according to Gazzoni (2013), for every 10 hectares cultivated with soybeans, it is estimated that direct and indirect employment is generated. The area occupied by pastures has shown a downward trend since 2006; the opposite was true for areas cultivated with sugarcane and soybean (Figure 3).

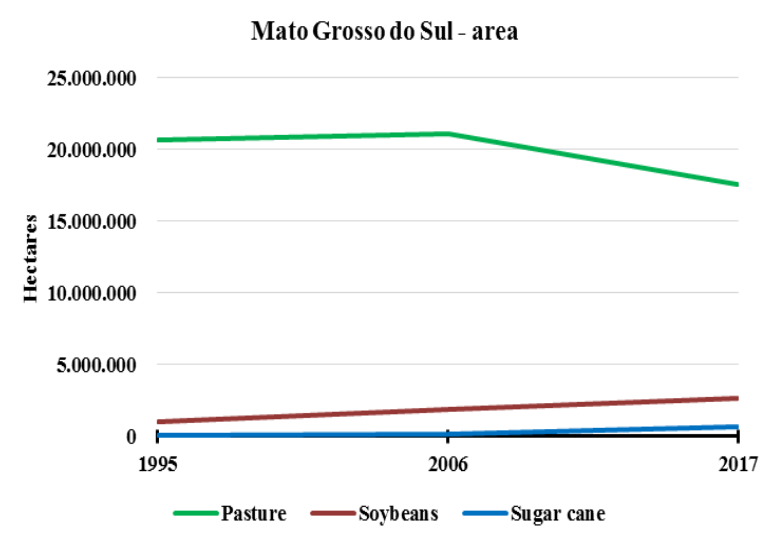

Figure 3. Planted area of soybean, sugar cane and pasture in Mato Grosso do Sul, from 1995 to 2017. Source: IBGE (1998, 2019b). 
The areas formerly occupied by pastures, especially in the eastern region of Mato Grosso do Sul, are now mostly being cultivated with eucalyptus, to meet the demand of the pulp industry located in Três Lagoas, and with rubber, which has undergone a major expansion in this region in recent years.

In summary, according to the 1995, 2006 and 2017 Agricultural Censuses, the area in the state planted with soybeans grew by $150.85 \%$, the area planted with sugarcane grew by $778.85 \%$, and the area occupied by pastures decreased by $14.81 \%$ (Figure 3 ).

\subsubsection{Municipalities evaluated}

\subsubsection{Area planted by municipality}

Information was collected for the main municipalities producing grain and sugar cane in Mato Grosso do Sul (a total of 14 municipalities (Table 1) according to the Agricultural Census conducted in 2017 by IBGE (2019b)), which represents $57 \%$ of the cultivated area in the state.

In the 14 municipalities evaluated, the area with pasture decreased within the period examined. In most cases, the reduction was more intense from 2006 onwards, which coincides with the increase in soybean acreage. The exception is Costa Rica, where the area under soybean cultivation was slightly reduced within the period evaluated. The reduction in pasture area in municipalities where beef cattle ranching has always been a prominent activity, such as Naviraí, Nova Alvorada do Sul, Sidrolândia and Ponta Porã, stands out in relation to that in the other municipalities (Figures $4 \mathrm{~A}$ to $4 \mathrm{O}$ ). In these municipalities, there was a significant increase in the areas cultivated with soy and sugar cane
(Figures 4I, J, K and M). An increase in agricultural area greater than that of pasture area was also observed (Souza et al., 2007; Vieira Filho, 2018 and Streck et al., 2018). However, the authors found an increase in herd numbers, that is, there is an intensification of production, with a larger number of animals per unit of area than that in other municipalities. During the period analysed, especially in the last decade evaluated, the cattle herd of Mato Grosso do Sul decreased by $10 \%$.

Considering that a significant part of the pasture area in Mato Grosso do Sul showed some degree of degradation, the improvement of livestock productivity invariably involves the recovery of these pasture areas. However, there seems to be no recovery of pasture in most situations, but replacement of pasture with agriculture. In Ponta Porã, Maracaju, Naviraí and Sidrolândia, the cattle herd in the period analysed was reduced by $55.31 \%, 52.68 \%, 37.59 \%$ and $23.07 \%$, respectively (Table 2 ).

As shown in Table 2, the quantitative reduction in beef cattle for most of the municipalities analysed in this paper was evident, which should be accounted for when considering the diversification of the economic matrix of any of the federated entities.

The reduction in the cattle herd and pasture area and the increase in area cultivated with soybean are based on economic issues. Beef cattle ranching, which formerly operated in an extensive system of low productivity, although low cost, also had low profitability. The beef cattle production system is intensifying, which frees up area for agriculture, especially with an integrated crop-livestock production model (Salton et al., 2017).

Table 1. Area and percentage of area occupied by sugarcane and soybeans in municipalities of Mato Grosso do Sul state in 2017.

\begin{tabular}{|c|c|c|c|c|c|}
\hline \multirow{2}{*}{ County } & \multirow{2}{*}{ Area (ha) } & \multicolumn{2}{|c|}{ Sugar cane } & \multicolumn{2}{|l|}{ Soybean } \\
\hline & & Area (ha) & $\%$ & Area (ha) & $\%$ \\
\hline Mato Grosso do Sul & $35.714 .553,10$ & 749.784 & 2,10 & 2.712 .162 & 7,59 \\
\hline Angélica & $127.326,80$ & 43.245 & 33,96 & 3.700 & 2,91 \\
\hline Aral Moreira & $165.566,00$ & - & - & 107.000 & 64,63 \\
\hline Chapadão do Sul & $324.812,00$ & 26.000 & 8,01 & 83.000 & 25,55 \\
\hline Costa Rica & $416.412,00$ & 45.896 & 11,02 & 73.000 & 17,53 \\
\hline Dourados & $408.623,70$ & 50.000 & 12,24 & 170.000 & 41,60 \\
\hline Ivinhema & $201.016,80$ & 54.174 & 26,95 & 17.000 & 8,46 \\
\hline Laguna Carapã & $173.406,80$ & 5.000 & 2,88 & 111.500 & 64,30 \\
\hline Maracaju & $529.918,40$ & 37.600 & 7,10 & 273.000 & 51,52 \\
\hline Naviraí & $319.355,20$ & 5.592 & 1,75 & 87.000 & 27,24 \\
\hline Nova Alvorada do Sul & $401.932,30$ & 93.829 & 23,34 & 31.000 & 7,71 \\
\hline Ponta Porã & $533.044,80$ & 42.470 & 7,97 & 215.000 & 40,33 \\
\hline Rio Brilhante & $398.739,70$ & 102.500 & 25,71 & 110.000 & 27,59 \\
\hline Sidrolândia & $528.640,50$ & 9.000 & 1,70 & 205.000 & 38,78 \\
\hline Sonora & $407.542,00$ & 15.113 & 3,71 & 56.500 & 13,86 \\
\hline Region total & $3.787 .571,00$ & \begin{tabular}{|l|}
530.419 \\
\end{tabular} & 14,00 & 1.542 .700 & 40,73 \\
\hline
\end{tabular}

Source: IBGE (2019b). 
Angélica - area (A)



Pasture $\longrightarrow$ Soybeans $\longrightarrow$ Sugar cane

\section{Chapadão do Sul - area (C)}



Pasture $\longrightarrow$ Soybeans $\longrightarrow$ Sugar cane

\section{Dourados - area (E)}



Pasture $\longrightarrow$ Soybeans $\longrightarrow$ Sugar cane

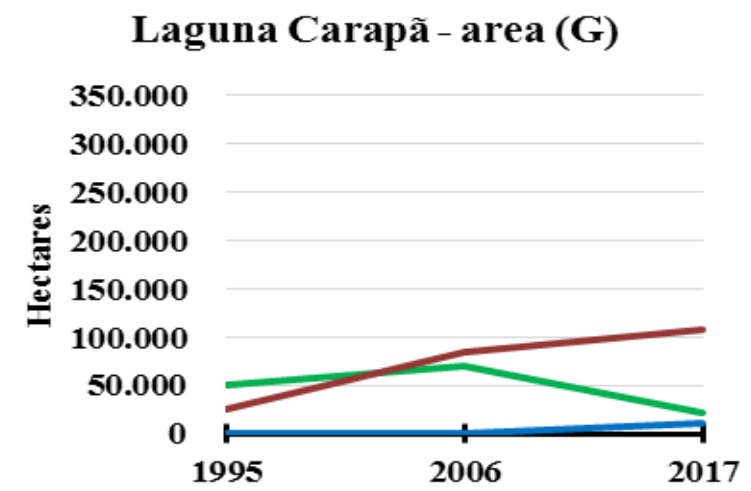

$\longrightarrow$ Pasture $\longrightarrow$ Soybeans $\longrightarrow$ Sugar cane
Aral Moreira - area (B)



Costa Rica - area (D)

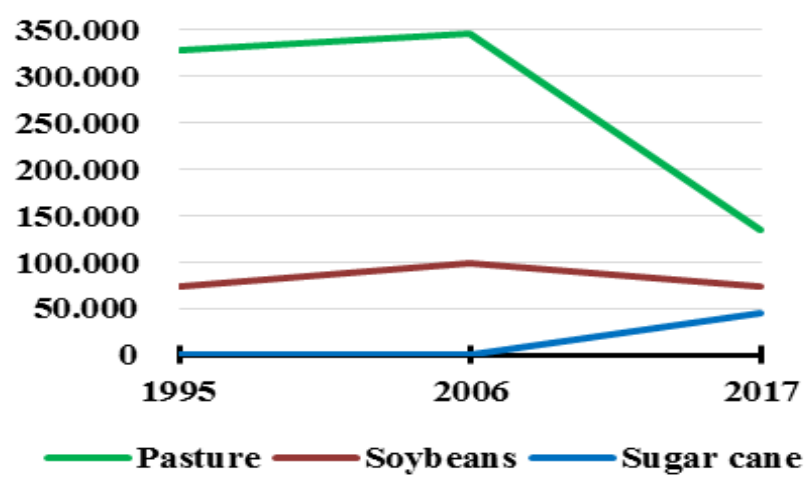

Ivinhema - area (F)



$\longrightarrow$ Pasture $\longrightarrow$ Soybeans $\longrightarrow$ Sugar cane






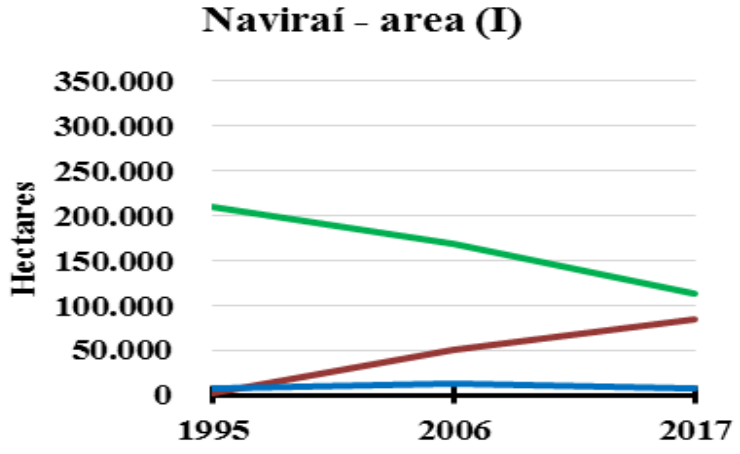

Pasture Soybeans Sugar cane

\section{Ponta Porã - area (K)}

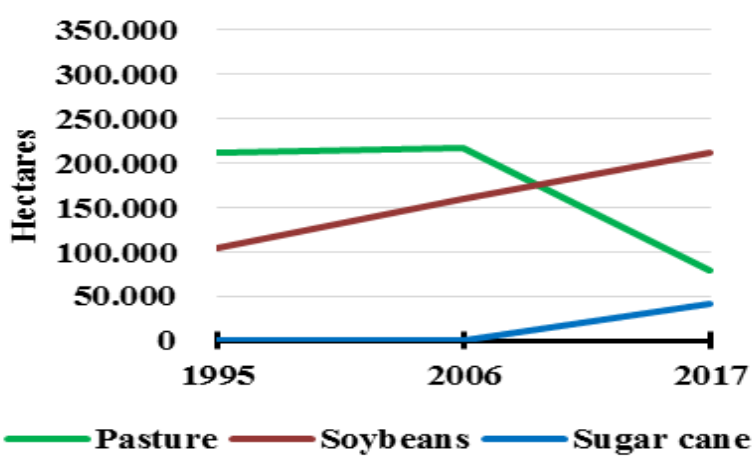

Sidrolândia - area (M)

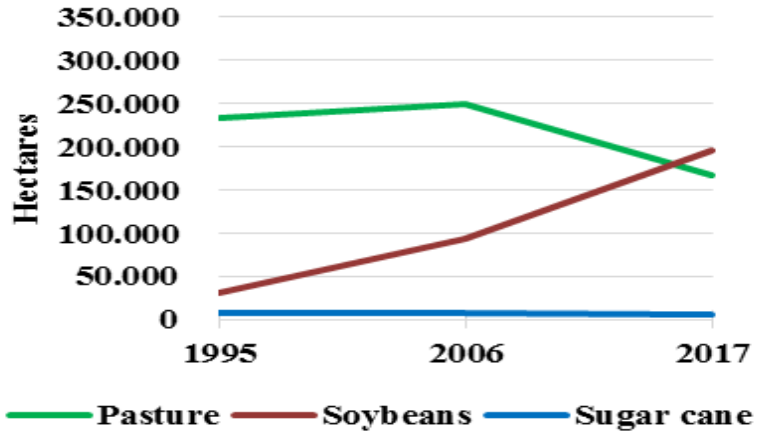

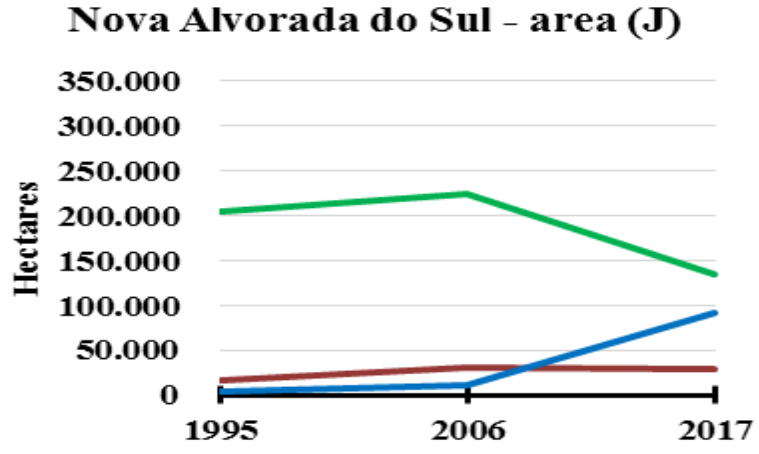

Pasture Soybeans $\longrightarrow$ Sugar cane

\section{Rio Brilhante - area (L)}


Figure 4. Evolution of the areas occupied by pasture, sugar cane and soybean from 1995 to 2017 in municipalities of Mato Grosso do Sul. Source: IBGE (2019b).

Table 2. Evolution of the cattle population from 1995 to 2017 in some municipalities of Mato Grosso do Sul.

\begin{tabular}{lccc}
\hline County & $\mathbf{1 9 9 5}$ & $\mathbf{2 0 0 6}$ & $\mathbf{2 0 1 7}$ \\
\hline Mato Grosso do Sul & $\mathbf{2 2 . 2 9 2 . 3 3 0}$ & $\mathbf{2 3 . 7 2 6 . 2 9 0}$ & $\mathbf{2 1 . 4 7 4 . 6 9 3}$ \\
Angélica & 128.368 & 128.827 & 65.261 \\
Aral Moreira & 111.587 & 65.018 & 32.500 \\
Chapadão do Sul & 208.097 & 226.068 & 145.200 \\
Costa Rica & 347.978 & 345.238 & 192.429 \\
Dourados & 291.546 & 235.849 & 148.185 \\
Ivinhema & 235.436 & 220.952 & 154.736 \\
Laguna Carapã & 132.908 & 73.020 & 41.627 \\
Maracaju & 380.185 & 327.412 & 179.903 \\
Naviraí & 312.780 & 239.825 & 195.191 \\
Nova Alvorada do Sul & 256.114 & 339.081 & 214.215 \\
Ponta Porã & 326.200 & 299.212 & 145.765 \\
Rio Brilhante & 253.436 & 228.324 & 113.087 \\
Sidrolândia & 367.315 & 371.691 & 282.563 \\
Sonora & 137.351 & 161.521 & 164.127 \\
\hline
\end{tabular}

Source: IBGE (2019b). 
With the appreciation of the soybean commodity, livestock ranching is no longer viable. Many of the areas cultivated with soybeans or sugar cane are managed by an entrepreneur who leases land, typically degraded pasture, to grow soybeans and corn. According to Salton et al. (2017), using soybean cultivation as a strategy for the recovery of degraded pastures results in great economic viability and is therefore a recommended alternative from both technical and economic perspectives.

Pasture improves soil structure, increases organic carbon stocks and reduces the survival of necrotrophic diseases and some crop pests. Soybean plants improve soil chemical attributes, favouring maize and pasture grown in succession. That is, the benefits of grazing and integrated grain crops are greater than the sum of the two parts of the system. This synergy between activities is the basic foundation of integrated production systems (Franchini et al., 2016).

\section{Conclusions}

The area cultivated with soybeans is growing, especially in municipalities that have had little "tradition in agriculture" until now;

There has been a replacement of pasture-occupied areas by agriculture; and

The reduction in pasture area is accompanied by a reduction in the cattle herds.

\section{Bibliographic References}

Biosul, 2019. Mapa da bioenergia em Mato Grosso do Sul. http://biosulms.com.br/estatisticas/ (Acessado 30 de outubro 2019).

Brasil, 2018. Ministério da Agricultura Pecuária e Abastecimento. Serviço de Inspeção Federal. Quantidade de abate estadual por ano/espécie: aves. Brasília, DF. http://sigsif.agricultura.gov.br/sigsif_cons/!ap_abate_estaduais _cons?p_select=SIM (Acessado 31 de outubro de 2019).

Conab, 2019a. Acompanhamento da safra brasileira de grãos: safra 2018/19: sétimo levantamento, Brasília, DF, v. 6, n. 7, 115 p. https://www.conab.gov.br/info-agro/safras/graos (Acessado 3 de abril de 2019).

Conab, 2019b. Acompanhamento da safra brasileira: cana-deaçúcar: safra 2019/20: segundo levantamento. Brasília, DF, v. 6 , $\mathrm{n}$ 2. file://C:/Users/silvia/Downloads/BoletimZCanaZ(28ZLevanta mentoZ19-20.pdf (Acessado 30 de outubro de 2019).

Contini, E., Gazzoni, D., Aragão, A., Mota, M., Marra, R., 2018. Complexo soja - caracterização e desafios tecnológicos. [Brasília, DF]: Embrapa, 35 p. (Série desafios do agronegócio brasileiro. Nota técnica, https://www.embrapa.br/documents/10180/0/COMPLEXO+S OJA+-

+Caracteriza\%C3\%A7\%C3\%A3o+e+Desafios+Tecnol\%C3\%
B3gicos/709e1453-e409-4ef7-374c-4743ab3bdcd6 (Acessado 17 de abril de 2019).

Embrapa, 2018. Visão 2030: o futuro da agricultura brasileira. Brasília, DF, 212 p.

FIESP, 2018. Outlook Fiesp 2028: projeções para o agronegócio brasileiro. São Paulo: FIESP, 86 p. http://hotsite.fiesp.com.br/outlookbrasil/2028/files/assets/basic -html/page-4.html (Acessado 28 de agosto de 2019).

Franchini, J.C., Vallini, C.L., Balbinot Junior, A.A., Debiasi, H., Watanabe, R.H., 2016. Integração lavoura-pecuária em solo arenoso e clima quente: duas décadas de experiência. Londrina: Embrapa Soja, 12 p. (Embrapa Soja. Circular técnica, 118).

Gazzoni, D.L., 2013. A. sustentabilidade da soja no contexto do agronegócio brasileiro e mundial. Londrina: Embrapa Soja, 50 p. (Embrapa Soja. Documentos, 344).

Hirakuri, M.H., 2017. Avaliação econômica da produção de soja nos Estados do Paraná e Rio Grande do Sul na safra 2016/17. Londrina: Embrapa Soja, 14 p. (Embrapa Soja. Circular técnica, 126).

Hirakuri, M.H., Lazzaroto, J.J., 2014. O agronegócio da soja nos contextos mundial e brasileiro. Londrina: Embrapa Soja, 70 p. (Embrapa Soja. Documentos, 349).

IBGE, 1998. Censo agropecuário 1995-1996. Número 23 Mato Grosso do Sul. Tabela 67: Utilização das terras, segundo Mesorregiões, Microrregiões e Municípios. Rio de Janeiro.

IBGE, 2019a. Sistema IBGE de Recuperação Automática. Banco de Dados Agregados. Tabela 1612: área plantada, área colhida, quantidade produzida, rendimento médio e valor da produção das lavouras temporárias. [Rio de Janeiro, 2019]. https://sidra.ibge.gov.br/tabela/1612 (Acessado 07 de fevereiro de 2019).

IBGE, 2019b. Sistema IBGE de Recuperação Automática. Banco de Dados Agregados. Tabela 6615: número de estabelecimentos agropecuários, quantidade produzida e área colhida, por produtos da lavoura temporária: resultados preliminares 2017. [Rio de Janeiro, 2019]. https://sidra. ibge.gov.br/tabela/6615 (Acessado 22 de fevereiro de 2019).

Nogueira, M.P., 2019. A evolução da área de pastagens no Brasil.

http://www.rallydapecuaria.com.br/index.php/node/1366

(Acessado 30 de outubro de 2019).

O Futuro é agro: 2018-2030, 2018. [Brasília, DF]: CNA: Conselho do Agro, 135 p. https://www.cnabrasil.org.br/documentos-tecnicos/o-futuro-eagro-plano-de-trabalho-2018-a-2030 (Acessado 17 de abril de 2019).

Salton, J.C., Arantes, M., Zimmer, A.H., Richetti, A., Tomazi, M., Kruker. J.M., Mercante, F.M., Kichlel, A.N., 2017. Sistema São Mateus: viabilidade técnica- econômica do sistema integrado de produção no Bolsão Sul-Mato-Grossense. Dourados: Embrapa Agropecuária Oeste, 11 p. (Embrapa Agropecuária Oeste. Circular técnica, 40).

Semagro, 2018. Políticas públicas favorecem troca da área de pecuária por lavoura sem reduzir rebanho e sem pressionar 
meio ambiente. http://www.semagro.ms.gov.br/ibge-confirmams-foi-unico-estado-produtor-a-aumentar-area-plantada-em2018/ (Acessado 30 de outubro de 2019).

Souza, G.S., Alves, E., Gomes, E.G., Gazzola, R., Marra, R., 2007. Substituição de culturas: uma abordagem empírica envolvendo cana-de-açúcar, soja, carne bovina e milho. Revista de Política Agrícola, 16(2), 5-13.
Streck, I.L., Pires, M.A.B., Silva, V.R., Luz, F.B., Rieth, L.G., Goergen, N., 2018. Diagnóstico da mudança de uso da terra para produção de soja no Rio Grande do Sul. Revista Plantio Direto \& Tecnologia Agrícola, 28(11), 13-18.

Vieira Filho, J.E.R., 2018. Efeito poupa-terra e ganhos de produção no setor agropecuário brasileiro. Brasília, DF: IPEA, 41 p. (IPEA. Texto para discussão, 2386). 